\title{
OPACITY AND TRANSPARENCY IN HISTORICAL REPRESENTATIONS
}

\author{
BRANKO MITROVIĆ
}

Meaning, Truth, and Reference in Historical Representation. By Frank Ankersmit. Ithaca, NY: Cornell University Press, 2012. Pp. xi, 264.

\begin{abstract}
In his latest book Frank Ankersmit develops a comprehensive philosophical perspective on the problem of the truth and reference of historical representations. The approach and the wider perspective of the book largely belong to what could be called the postmodernist paradigm, in spite of some recent attempts to interpret Ankersmit's recent work differently. Since his 1983 Narrative Logic Ankersmit has propounded the view that individual statements that constitute historical representations may have reference, but that representations themselves do not. This most recent book remains faithful to this position and elaborates it further. This essay examines Ankersmit's arguments as well as the assumptions and implications of this view.
\end{abstract}

Keywords: Hayden White, postmodernism, antirealism, colligatory concepts, reference of historical narratives

Perché vi sia specchio del mondo occorre che il mondo abbia una forma. ${ }^{1}$

Frank Ankersmit's works have had a long history of harsh reviews and hostile polemics, often deriving from his critics' misunderstandings of some of his central claims. This does not make it easy to attempt a review of his latest book. The task is made even harder by the fact that the book is wider in its philosophical perspective than, for instance, his Narrative Logic or Historical Representation. ${ }^{2}$ One should also bear in mind that this is a philosopher's book for philosophers of history. Regrettably, one may predict that historians might be discouraged from giving the book the consideration it deserves because of its poor attention to scholarly details, the absence of engagement with real historical works, as well as occasional clumsy formulations. ${ }^{3}$

1. Umberto Eco, Il nome della rosa (Milan: Bompiani, 1993), 127. ("In order for there to be a mirror of the world, it is necessary that the world have a form.")

2. Frank Ankersmit, Narrative Logic: A Semantic Analysis of the Historian's Language (The Hague: Martinus Nijhoff Publishers, 1983); idem, Historical Representation (Stanford: Stanford University Press, 2001).

3. It is fair to say that the book is below the standard editorial level of scholarly publications in the humanities today. There is no bibliography, the use of footnotes to establish the sources that Ankersmit cites is cumbersome, and in some important sections they are not stated (for example, Hölderlin, 171). Important discussions are based on popular secondary sources (for instance, the 
The book thus has to be taken on its philosophical merit; the (missing) refinements of historical scholarship have to be disregarded if one is going to give it a fair reading. It restates, in a very comprehensive perspective, Ankersmit's old positions about historical representation and narration. His early Narrative Logic was read as a "postmodern theory of narrativity," and the early Ankersmit was seen as affiliated with "extreme postmodernist" positions. ${ }^{4}$ For those who read Ankersmit that way, his later work, including this latest book, may be seen as a story of gradual distancing from postmodernist and antirealist positions. ${ }^{5}$ But one may also think that this later "development" was already present in nuce in his early works, and that which appears to be a gradual change of view may be a mere rearticulation of certain positions triggered by the criticism and approvals that his work has received over time.

I

The central topic of Ankersmit's book is the nature of historical narrative representations, their reference and truth. The problem, which has been widely debated by philosophers of history since the 1980s, goes like this. ${ }^{6}$ Historical narratives consist of statements, and these statements are true or false depending on how successfully they describe the events they refer to. It is, however, much harder to say how to establish the reference, truth, or falsity of historical narratives and

presentation of Hegel's views on 22-25 is based on Beiser). Greek words are used with accents misplaced (110-113), lack accents (188), or lack the breathing sign (110-113, 188). A number of clumsy formulations are likely to undermine the credibility of the book in a historian's eyes. For instance, Ankersmit, Meaning, Truth and Reference, 31: Kant, "as a typical representative of the Enlightenment he had neither interest in nor respect for historical writing." (Were Gibbon, Hume, and Voltaire atypical representatives of the Enlightenment?) Or 166, note 10: "Gumbrecht argues that the word est in hoc est corpus meum was originally taken literally, whereas since the Reformation the word has been read as 'standing for'." But historians will certainly know that this is the official theology of the Catholic Church; for instance, John Paul II in his Dominicae Cenae ("On the Mystery and Worship of the Eucharist"), February 24,1980, spoke about the "public worship rendered to Christ present in the Eucharist" and "in it [the Eucharist] are the continual presence and action of Christ." Similarly, an art historian who reads: "according to Hans Belting, Byzantine icons were believed to participate in the God's essence on the basis of some (neo-) Platonic assumption" (166) is likely to expect this "some (neo-) Platonic assumption" to be specified and would prefer to see a consideration of primary sources (John of Damascus?) rather than Hans Belting. The claim (discussed below) that there is no evidence that the Renaissance happened is certainly going to disqualify the book from serious consideration by many historians. Finally, hardly any historians, except Huizinga, are discussed, and even he receives attention mainly for a bizarre theory that we do not perceive things through individual senses, but rather that we somehow experience things first independently of our senses and only then do our minds classify that experience into visual, auditory, and so on (200-203).

4. Heikki Saari, "On Frank Ankersmit's Postmodernist Theory of Historical Narrativity," Rethinking History 9, no. 1(2005), 5. John Zammito, “Ankersmit and Historical Representation," History and Theory 44, no. 2 (2005), 156.

5. See, for instance, Peter P. Icke, Frank Ankersmit's Lost Historical Cause: A Journey from Language to Experience (New York: Routledge, 2012).

6. For formulations of the problem outside Ankersmit's opus, see, for instance, Hayden White, "The Value of Narrativity in the Representation of Reality," in idem, The Content of the Form: Narrative Discourse and Historical Representation (Baltimore: Johns Hopkins University Press, 1987), 1-25. Also, David Carr, "Narrative and the Real World: An Argument for Continuity," History and Theory 25, no. 1 (1986), 117-131, and C. Behan McCullagh, "The Truth of Historical Narratives," History and Theory 26, no. 1 (1987), 30-46. 
representations that are made up of individual statements. No historian can report about everything; the statements he or she includes in a narrative refer to selected events and taken together constitute a historical representation. The question is, what is the reference of this totality and how can we say that it is true or false? Historians structure historical representations as narratives, but historical reality itself does not have the structure of a narrative. Historical reality itself does not have the form of literary works; it is not prepacked into story-like conglomerations of events that have plots and the structure of stories. ${ }^{7}$ As David Carr put it, "Real events do not hang together in a narrative way ... in virtue of its form any narrative account will present us with a distorted picture of the events it relates." So how can one say that historical representations refer to the historical past, if the past itself has no narrative structure they could refer to? Or, to paraphrase C. Behan McCullagh, can we actually say that a historical representation bears any more resemblance to the past than a bouquet of flowers does to the garden from which it was picked?

One important aspect of the problem is that historical narratives say more than the individual statements that make them up. The truth and reference of historical representations cannot be reduced to the mere sum (conjunction) of the truthvalues and references of the propositions expressed by the sentences that make up the narrative. In the past, some of Ankersmit's critics did not grasp this important point. ${ }^{10}$ Consider, for instance, what Gibbon says about Peter the Hermit:

He was born of a gentleman's family (for we now must adopt a modern idiom), and his military service was under the neighbouring counts of Boulogne, the heroes of the first crusade. But he soon relinquished the sword and the world; and if it be true that his wife, however noble, was aged and ugly, he might withdraw with the less reluctance from her bed to a convent, and at length to a hermitage. In this austere solitude his body was emaciated, his fancy was inflamed; whatever he wished, he believed; whatever he believed, he saw in dreams and revelations. From Jerusalem the pilgrim returned an accomplished fanatic; but as he excelled in the popular madness of the times, Pope Urban the Second received him as a prophet, applauded his grand design, promised to support it in a general council, and encouraged him to preach the deliverance of the Holy Land. ${ }^{11}$

Gibbon does not make the statement that Peter the Hermit went to Jerusalem. It is nevertheless enough to know that Boulogne is not in the neighborhood of Jerusalem to grasp that one could not have returned from Jerusalem without having gone there. A historical narrative or representation is thus not mechanically reducible to the sum of individual statements; it says much more. Interaction between statements as well as their interaction with the reader's beliefs (knowledge) and the

7. As Hayden White pointed out: "The notion that sequences of real events possess the formal attributes of the stories we tell about imaginary events could only have its origin in wishes, daydreams, reveries. Does the world really present itself to perception in the form of well-made stories, with central subjects, proper beginnings, middles, and ends, and a coherence that permits us to see 'the end' in every beginning?" White, "The Value of Narrativity," 24.

8. Carr, "Narrative and the Real World," 117.

9. C. Behan McCullagh, review essay of F. R. Ankersmit, Narrative Logic: A Semantic Analysis of the Historian's Language, History and Theory 23, no. 3 (1984), 394-403.

10. Ibid., 395.

11. Edward Gibbon, The Decline and Fall of the Roman Empire (New York: Random House, n.d.), III, 418 . 
beliefs (knowledge) that the author attributes to the reader, contribute to the content as well. The total sum of the propositions that a historical narrative expresses also includes the propositions that are implied by the style and the rhetoric the historian uses - for instance, the author may use irony in order to reveal his or her value judgments about the events described. Ranke in Die serbische Revolution describes the activities of the Turkish fleet off the coast of Italy during the Second Coalition against Napoleon: "a joint Turkish-Russian fleet appears off the coast of Italy; the Caliph of Rum, as was the Sultan's proper title, made the efforts to reinstall the Pope in Rome." 12 The sentence describes a fact-Turkish political aims behind a certain naval intervention - but the phrase "Caliph of Rum" is obviously used in order to remind the readers of the absurdity of the situation, in the wider religious and historical context that (the sentence also indicates) Ranke expects his readers to be aware of. It also conveys Ranke's own judgment of the events. There is thus a whole set of propositions conveyed by the sentence, in addition to the one that describes the activities of the Turkish fleet.

The propositions that express all this are in the text; the decision to privilege or consider only some of them (for instance, those that describe facts or that depend on rhetorical structure) belongs to readers, who may have different interests. In his "Historicism, History, and the Figurative Imagination," Hayden White analyzed a brief paragraph from A. J. P. Taylor's The Course of German History in order to point out that literary conventions and rhetoric support the historical explanation the paragraph provides..$^{13}$ Taylor argued that the real life of the Weimar Republic was much shorter than the period 1919-1933: the first four years were marked by the confusion that followed the war; during the last three years a temporary dictatorship "half cloaked in legality . . . reduced the republic to a sham long before it was openly overthrown." White's careful analysis presents a series of propositions that can be derived from the literary structure of the text and its rhetoric. Precisely because his analysis recovers these propositions so successfully, it is much harder to follow him in his claim that the explanatory effect of Taylor's writing derives from "its appeal to certain conventions of literary characterization." ${ }^{14}$ One would much rather say that the explanatory effect derives from the propositions conveyed using certain literary conventions - after all, literary conventions themselves cannot explain anything, but the propositions they convey can. Simply, a historical text conveys a set of propositions, some of which are expressed using more literary or rhetorical means than others or express the author's judgment: a historian who calls the political life of an era a "sham" knows that he is expressing a value judgment and expects the readers to recognize the truth of the corresponding proposition ("The author thinks ..."). But this is a proposition like any other expressed

12. Leopold von Ranke, Die serbische Revolution (Berlin: Duncker und Humblot, 1844), 181.

13. He actually claims that the explanatory effect derives from the appeal to literary conventions (107). Hayden White, "Historicism, History, and the Figurative Imagination," in Tropics of Discourse, Essays in Cultural Criticism (Baltimore: Johns Hopkins University Press, 1978), 107-114 (originally published in History and Theory 14, no. 4, Beiheft 14: Essays on Historicism [1975]), 48-67).

14. Ibid., 107. Note that White's analysis has to consist of the propositions that can be recovered from the text: if he could not state the propositions conveyed by literary and rhetorical means, he could not specify the relevance of the rhetorical and literary aspects that he wants to attribute to them. 
by the text; White never explains why one should privilege propositions conveyed by the means of rhetoric or literary structure over other propositions that one can read in a text. ${ }^{15}$

When discussing the truth, reference, or meaning of historical representations, one can consequently choose between two approaches. The transparent approach would be to think that they are in some way describable as functions of the reference, meaning, truth, and so on of the totality of propositions expressed by the narrative (not only the individual sentences) - whereas the opaque view would be that they are not. White's is an example of the opaque position, since in his view a historical discourse does not merely select facts for presentation, but distorts them. ${ }^{16}$ In the above example, he says, the real referent, created by "fact and figurative characterization," is an image of an object quite different from the manifest referent (Germany itself). Ankersmit's book can be characterized as an attempt to formulate a wider and more comprehensive opaque theory of historical representations that would not reduce them to a single aspect of historical works, such as their literary structure. As he puts it: "[W]e must abandon our hopes to see the past itself through the historical text. . . Language is the clay, so to speak, out of which the historian models his representations, and it also is as nontransparent as clay typically is" (198).

II

The origin of Ankersmit's theory of historical representation is in W. H. Walsh's discussion of "colligatory concepts"- the concepts that historians use in order to organize what originally looks like an unorganized mass of material. ${ }^{17}$ Walsh pointed out that such concepts must be "well founded as opposed to arbitrary, tailored to fit the facts rather than a straitjacket into which the facts must be forced whatever their particular nature." 18 They are useful insofar as they illuminate the past. ${ }^{19}$ Ankersmit's important departure from Walsh is to cancel the relationship between historical representations and facts; he claims that historical representations do not have reference. He thus differentiates between descriptions and representations. A statement is a description in the sense that it has a definite propositional structure, such as "A is f." This structure enables us to differentiate between the part of the statement that refers and the predicate part that attributes a property. Ankersmit points out that in the case of a book about the French Revolution, for example, it is impossible to find chapters that refer to the Revolution and others that describe its properties (66). Such a book (representation) does not have the structure of a statement and, he infers, it cannot refer. It is interesting

15. He clearly suggests that they constitute "deeper"- presumably, this is a value judgment meaning "more profound" - level: "The facts and their formal explanation or interpretation appears as the manifest or literal 'surface' of the discourse, while the figurative language used to characterize the facts points to a deep-structural meaning." Ibid., 110.

16. Ibid., 111.

17. W. H. Walsh, "Colligatory Concepts in History", in The Philosophy of History, ed. Patrick Gardiner (Oxford: Oxford University Press, 1978), 136.

18. Ibid., 139.

19. Ibid. 
to contemplate whether this argument suffers from circularity: Ankersmit's book itself does not have the form "A is f," and following the same reasoning, what the book says about historical representations (his representation of historical representations) could not refer to them nor be true..$^{20}$ Nevertheless, this does not prevent his individual statements from being true.

In any case, Ankersmit points out that his view is not that historical representation functions on the free-for-all principle, but rather that "the criteria of propositional truth and falsity will be of no help" (67). Also, he does not deny that the statements that make up a representation refer, but that their totality does not; a representation is a totum and not a compositum (79). In other words, no analysis of the statements that together make up a historical representation can provide us with the reference of that representation, even though these statements themselves refer-and it is in this sense that one can say that historical representations as he describes them are opaque.

The implications of Ankersmit's claims are well illustrated by the discussion of his position's similarity with German historicism of the nineteenth century, especially that of Ranke and Humboldt. The fact that Ankersmit claims Wahlverwandtschaft with German historicism may disturb some politically alert readers, since historicism is traditionally associated with right-wing politics, the glorification of the state, and the view that individuals cannot have or claim rights beyond those granted to them by their political environment. ${ }^{21}$ It is therefore important to mention that Ankersmit's book does not express support for such views; toward the end of the book he talks (maybe too optimistically) about the historian's focus

20. See Ian Verstegen, A Realist Theory of Art History (Oxford: Routledge, 2013), 8-9 for a discussion of such self-excepting fallacies.

21. Remarkably, in his Narrative Logic, Ankersmit even talks about "the historicists' defense of human freedom" (202). However, as Georg Iggers describes, "Ranke never acknowledged the rights of the individual against the state"; his position involves "a radical rejection of the theory of natural law and of the rights of man." (See his Introduction to Leopold von Ranke, The Theory and Practice of History, ed. Georg Iggers [Oxford: Routledge, 2011], xxi, xxxii). In his Geschichte der romanischen und germanischen Völker, Ranke glorifies the extermination (ausrotten) of the Slavic population west of the Odra as "glänzender Erfolg" (Leopold von Ranke, Geschichten der romanischen und germanischen Völker von 1494-1514 [Hamburg: Standard-Verlag, 1957], 12). Ernst Troeltsch similarly rejected the idea that humans can have some rights by their nature as a surrogate of the Enlightenment; the very idea of humanity (let alone human rights), he argues in Der Historismus und seine Probleme, is a construct of the eighteenth century. (Ernst Troeltsch, "Die Krisis des Historismus," in idem, Lesebuch: Ausgewählte Texte, ed. Friedman Voigt [Tübingen: Mohr Siebeck, 2003], 249; idem, Der Historismus und seine Probleme. Erstes Buch: Das logische Problem der Geschichtsphilosophie [Tübingen: J. C. B. Mohr, 1922], 193-195). Similarly, Friedrich Meinecke in his Enstehung des Historismus praises the works of Justus Möser, who articulated, as he says, "before the [French] Revolution the intellectual arms with which the historical rights of state and society were defended against the universality of human rights" (Friedrich Meinecke, Die Entstehung des Historismus [Munich: Leibniz Verlag, 1946], 343). In the 1933 "Geleitwort" to Historische Zeitschrift, 150 (1934), 9, Meinecke stated that "Die nationalsozialistische Revolution fühlt sich getragen von Kräften des Blutes und der Rasse, die aus fernster Vorzeit stammen. . . . Diese positive Auswirkungen [der nationalsozialistischen Revolution] wird jeder deutsche Historiker, kann er denken wie er will, anerkennen und mit Freuden fördern können.” After 1945, when he changed his judgment about National Socialism, he blamed the Jews, among others, for the rise of Hitler, see Friedrich Meinecke, Die Deutsche Katastrophe: Betrachtungen und Erinnerungen (Wiesbaden: Eberhard Brockhaus Verlag, 1946), 29. One can go on citing similar examples from the writings of the prominent protagonists of historicism; Ankersmit's claim about their "defense of human freedom" can only be taken as grotesque in the extreme. 
on "the dimension and exploits of human freedom and on where the exercise of political freedom may make a difference to the world" (256). Rather, historicism is important for Ankersmit because he believes that Ranke's and Humboldt's notion of "historical idea" is similar to his "historical representations." "The historical idea is, basically, a claim about how a nation's or an epoch's most important features hang together," he observes (11). But here is the big difference: Ranke's and Humboldt's "historical idea" is operational in the world and determines human actions, whereas Ankersmit rejects, as he says, the "parallelism of language and reality" and claims that the historical idea should be located in the historian's narrative, rather than in the past: "It is not an entelechy determining the temporal development of historical objects but rather the principle structuring the historian's stories about the past," whereby one should avoid the assumption that the past contains some real counterpart to this structuring principle (13).

The endorsement of historicism that Ankersmit understands as "the view that the nature of a thing lies in its history" (1) announces the essentialist commitments that influence Ankersmit's arguments at some crucial moments later in the book. The very phrase "the nature of the thing" assumes that things have their natures, essences, that-which-it-is-to-be-that-thing. The alternative view could be that things have multiple descriptions that identify them equally well with equal precision - and that's all. Stating the thing's history would then be just one of the ways to identify it. The essentialist position is also implied in the claim that "the objects investigated by the historian cannot be defined apart from their history" that Ankersmit infers from this definition of historicism (2). ${ }^{22}$ This claim could hardly be true, since historians must be able to define and identify their objects of study before and in order to be able to study their history. An architectural historian who studies the use of Ionic bases in Roman baroque must be able to define and identify them on the basis of their shapes in order to recognize them on buildings; what one knows about the history of the Ionic base is of little help if one cannot identify it on the building. An archaeologist can study artifacts without knowing much about their history, and in fact infer much about their history from such study - which would not be possible if he or she had not been able to define and identify them previously.

22. Even more radically, he claims that "no historian can avoid subscribing to historicism. For what could possibly be the purpose of his activity if he rejected the historicist claim that a thing's nature or identity lies in its past." When he subsequently states that "Historicism, as just defined, was a German invention" (4), the reader is left to wonder how historians such as Herodotus or Vasari could have subscribed to historicism before it was invented. The claim is also false, because it implies that all historians must share the metaphysical belief that things have their natures, their essences, and that among various equally precise identifying descriptions of an object one should be privileged. Finally, Herodotus and Vasari stated the purpose of their writing in the opening sections of their books, and what they say has nothing to do with the purpose Ankersmit wants to impute to all historians. 
Arguably, the most important and also the most controversial aspect of Ankersmit's position are his arguments against the view that historical representations have reference. The arguments are:

a) The subjects of statements in a historical representation refer to a great number of different objects. It is therefore impossible to state the representation's object of reference (66). The background assumption is that the object of reference cannot be a set of items (events or things). The term "Renaissance," he explains, has no reference because there is no "unique individual thing in the past" that it could be said to refer to (145). Reference, according to Ankersmit, picks out unique objects in the world, whereas "unlike reference, representation does not pick out unique individual things" (94). From this point of view, "this plank's center of gravity" also "does not refer to some unique individual thing that could function as its object of reference" (92). ${ }^{23}$ In other words, no identifiable objects correspond to it (92), and since no "single individual thing" corresponds to the notion of "this plank's center of gravity," no true synthetic statements can be made about it (94). Once such an understanding of reference is adopted, it is indeed impossible to say that "Renaissance" or "French Revolution" refer to (large sets of) events, because events are not things. The same applies to battles, dimensions, time periods, the speed of an object, gravity, evolution, causation, and many other terms and phrases that will have no reference because they do not pick out unique individual things. The phrase "the Venetian ships in the battle of Lepanto" also has no reference because it does not identify a unique individual thing. Radical nominalism of this kind leaves without reference many phrases historians ordinarily use. It is patently useless to argue against an argument based on definition, but one should note that if the reference of "Renaissance" or "French Revolution" is an empty set, as Ankersmit suggests, then it follows that the sentences "the Renaissance happened" or "The French Revolution happened" are false.$^{24}$ Further, insofar as historical representations themselves are not physical objects, Ankersmit's own statements about historical representations cannot be said to refer to them, or be true on the basis of their reference. ${ }^{25}$ Worst of all, if reference is a relationship between words and individual material objects, then the very word "reference" will have no reference, since a relationship is not a material thing. But if the reference of "reference" is an empty set, then no word refers to anything.

b) The second argument is that it is impossible to fix the reference of words such as "baroque" or "the Renaissance," and that attempts to individuate the Renaissance can at most give us necessary, but never sufficient, conditions for fixing the reference of the term (145). The reference of "Renaissance," Ankersmit

23. See also Ankersmit, Narrative Logic, 180, for the same example.

24. "[T]here existed no Renaissance or Enlightenment in the way ... Napoleon existed" (81).

25 . This argument assumes that we do not identify historical representations with physical books. 
claimed in Historical Representation, differs in Burckhardt, Michelet, Huizinga, Wölfflin, and so on. ${ }^{26}$ We may have "the same associations" with the term "Renaissance," but this is merely a necessary condition that is not enough to fix the reference. Ankersmit used the same argument in his earlier exchange with Heikki Saari. ${ }^{27}$ Different historians had different things in mind when they wrote about the French Revolution. It is thus not clear "What exactly is this French Revolution... . Does it include Robespierre's having had breakfast on the morning of 20 March 1791? Even more so, does it include the kinds of things that historians in, say, $2200 \mathrm{AD}$ - and thus still unknown to us - will mention in their histories of the Revolution?"28 The next move in the argument is to ask, "Can you refer to an $\mathrm{x}$ that is unknown to you? What does it mean to 'refer' to something that expands or shrinks with the vagaries of historical debate?" 29 However, the fact that various individuals use a term to refer differently does not mean that the term has no reference-it means that it has different reference when used by different individuals. It would be hard to find a word or a term in any language that was not used in a nonstandard way sometime by someone. (I say: "The chair is in the corner." My friend says: "Not quite in the corner, but close." We disagree about what counts as "corner," but this does not mean that the room is circular..$^{30}$ ) It is normal that scholars engaged in a historical debate, at some point, may have to consider whether they are talking about the same things when they use certain words. ${ }^{31}$ Ankersmit actually accepts that "All the sentences on the past contained in some historical text on the Renaissance self-referentially fix the reference of the word 'Renaissance' for this specific text" (146). It would therefore be better to talk about Renaissances (in the plural) than about the Renaissance, he says (146). In this form, the argument seems hardly controversial, for it merely means that the term has different reference (refers with some variation) when used by different scholars.

c) In 2005, Heikki Saari suggested that Ankersmit's position may imply the denial of the Holocaust - if historical representations have no reference, then this will apply to the Holocaust too. ${ }^{32}$ Saari overlooked the fact that for Ankersmit, representations consist of statements in which reference to the past is made. Ankersmit was thus able to respond that the descriptions of the Holocaust and sentences that include reference to it can be true on the basis of overwhelming

26. Ankersmit, Historical Representation, 40.

27. The same argument is stated in Frank Ankersmit: "Reply to Professor Saari," Rethinking History 9 , no. 1 (2005), 26.

28. Ibid.

29. Ibid.

30. I am indebted to Nick Zangwill for this argument.

31. As John Searle pointed out, "it is a condition of a precise theory of an indeterminate phenomenon that it should precisely characterize that phenomenon as indeterminate; and a distinction is no less a distinction for allowing for a family of related, marginal diverging cases." John Searle, "The World Turned Upside Down," The New York Review of Books 27 (1983), 78.

32. "On his theory, historians' narratives and interpretations about what happened in the Nazi concentration camps merely 'organize' their historical insight about them. It follows from his anti-realist and constructivist position that historians cannot know whether there were concentration camps in Germany during the Second World War and whether or not the Nazis killed millions of their prisoners, because he claims that we have access only to texts in which these events are described." Saari, "Ankersmit's Postmodernist Theory," 16. 
evidence. Nevertheless, at the level of historical representation, it may seem that, for the same reasons as in the case of "Renaissance" (since the Holocaust was not an individual material thing), it follows from Ankersmit's position that the sentence "The Holocaust happened" is false. His latest book therefore attempts to avoid this situation by describing something like a spectrum of reference, whereby terms have reference according to their position on the spectrum. On the one end are Caesar or Napoleon, whose names refer to specific historical personalities; on the other, concepts such as the Renaissance, whose primary task is to organize our knowledge of the past into a coherent and consistent whole (82). Ankersmit actually claims that terms such as "the GNP of France in 1950" refers to an individuality that has the same ontological status as Caesar or Napoleon (82). He then goes on to say that because of overwhelming evidence the term "Holocaust" is much closer to "the GNP of France" than to "the Renaissance." The latter is "a purely representational term that has no counterpart in the past itself" (83). But it is not clear that this distinction can really be made: in the case of the Renaissance, as in the case of the Holocaust, overwhelming historical evidence exists that it happened.

The understanding of the term "reference" in all three arguments is mutually contradictory. In the second argument it is accepted that the sentences of a historical text "self-referentially fix the reference of the word 'Renaissance' for that specific text" (146), although according to the first argument it could have no reference because it is not a single material object. At the same time, according to the third argument, a non-thing (such as the GNP of France) can have reference if there is "overwhelming evidence" that it exists (83). But then it is not clear why "this plank's center of gravity" has no reference (92). Finally, if there are different Renaissances according to different authors (second argument), then it is not clear that one can claim that there is no evidence that the Renaissance happened (third argument), because it possible that some authors may fix the reference so that there is evidence.

One should expect that in the eyes of many professional historians (including me) something must have gone very wrong with a philosophy of history that claims that there is no sufficient evidence that the Renaissance happened and that therefore it did not happen. It should therefore be mentioned that Ankersmit still does not think that the term "Renaissance" is "meaningless, arbitrary or mere speculation" (83). He believes that such terms are "indispensable for rational discussion of history" and the possibility of such discussion is proven by the progress of the historical debate since Michelet or Burckhardt (83). Nevertheless, he says nothing about the criteria by which one could measure the progress of the debate about this nonexisting something. No historian will ever succeed "in fixing the reference of the word 'Renaissance'," he says, but this debate "enriches our understanding of the past" so this is "a most rational and valuable enterprise" (145). But he does not explain how our knowledge of the past can be enriched by a debate about the reference of the term that "has no counterpart in the past itself" (83). Why would such debates continue, once Ankersmit has explained to historians that "Renaissance" cannot have reference? All these contradictions are perplexing and one is not sure how to understand Ankersmit's efforts to avoid 
free-for-all relativism when it comes to the use of terms such as "Renaissance" or "French Revolution." It is not even clear how to tell one from the other. On what grounds could we say that a historian who claims that the French Revolution was actually the Italian Renaissance is wrong? Neither of the two happened; there is no evidence that they happened; notoriously, historians cannot agree on how to fix the reference of these two terms. So how can we possibly differentiate between the two?

IV

Ankersmit replaces reference with "aboutness" - as he puts it, historical representations do not refer to, but they are about historical reality. His account thus differentiates between: (1) the world itself (that is, historical reality), (2) the aspects of the world to which we have access through representation (3), historical descriptions (statements and their combinations), and (4) historical representation (79). The theory of aspects is crucial for the understanding of his views on historical representations. Consider two portraits of Napoleon that can be very different from each other: in this case their representeds must differ as well, "insofar as a represented is what is represented by a representation" (69). Ankersmit rejects the possibility that what is represented in the case of such portraits should be identified with Napoleon (69). He argues that in the case of a photograph that shows one and the same person from different perspectives, it would be wrong to say that each time, the represented - the person in the picture - is the same (69). This "would fail to do justice to the fact that what is being represented in one photograph is the person's profile, in another one his back and so on" (69). Similarly, in the case of a book about the French or Russian Revolution, it will always show us only aspects of these events (71)..$^{33}$ Various books on Napoleon "present us with aspects of Napoleon," and it is merely the sloppiness of language that leads us to say that they are about Napoleon himself (71). Few readers will agree with this view. It seems to suggest that after the police have photographed me driving my car over the speed limit, I can refuse to pay the speeding ticket on the basis of the argument that they've only photographed an aspect of my car, but not my car itself - that they want to charge me the fine merely because of the sloppiness of their language use.

It is in the discussion of "aboutness" and the truth of historical representations that Ankersmit's presentation becomes very hard to follow. What he tells us is that the historical text, at the level of representation, "is a "speaking about speaking": it speaks how to relate speech to the world" and he uses "aboutness" for characterizing this speaking about speaking (79). One gathers that Ankersmit

33. There is some confusion about the nature of aspects - that is, whether they are properties or not. Ankersmit says that presenteds "are aspects of (the) thing(s) that a representation represents and not these things themselves" (103). Aspects should not be "confused with a thing's properties, since properties do not depend on representations but on what can be expressed about things in terms of statements" (103). He also says, "Aspects are less than things and more than properties and must be located somewhere between the two of them" (106). But then on p. 111 one reads: "Presenteds [that is, aspects] ... are always loose bundles of properties in the absence of unique identifiable things to which they can be tied." He then continues talking about aspects as "loose bundles of properties" on p. 112. 
does not want to say that a historical representation is a metalanguage that pertains to historical language. Nor does he want to sever all ties with reality (80). "Speaking about speaking" sounds like the claim that in their historical narratives historians merely study the stylistic and rhetorical features used by other historians in their historical narratives. Arguably, this is not how most historians conceive of their work, and it is not clear how Ankersmit would counter their response that "aboutness" does not describe what their historical representations are about. (It is hard to see how the drawings of a building in an architectural historian's survey of that building can be said to be "speaking about speaking": they are about a physical building, and drawings are not speech.)

The discussion of truth in historical representations is heavily marred by the lack of clarity and the absence of historiographical examples. On the one hand is propositional truth whose home is language, as he says (109); on the other,

truth may also choose its home in the world itself. This is the case when a representation sends us to its presented (or aspect). For this presented is an aspect (part of) the world. Next, both thinghood and generality are embryonically present in the presented aspect already-hence the two items may be combined in a true or false sentence. This gives us the ontological truth of representation. Truth here is a property not of language but of the world and its things. (109)

Ankersmit defines representational truth "as what the world, or its objects, reveal to us in terms of its aspects" (107). Representational truth addresses the world in terms of aboutness and

can give us a hold on a "deeper" or "quasi-metaphysical" level of the world than what can be captured by the true statement. The price to be paid for getting access to this deeper level is a loss of articulateness in the sense of excluding propositional truth.

But if we are willing to pay that price, representation will effect a self-revelation of the world to us. (109)

He further relies on Heidegger: "in agreement with Heidegger's $\alpha \lambda \eta \dot{\eta} \theta \varepsilon \iota \alpha$ [sic] or Unverborgenheit, representational truth is a revelation of reality. Not language but reality itself ignites here the light of truth, although this self-revelation of reality can be achieved only through representation" (112). Ankersmit nevertheless claims that

whereas Heidegger's $\alpha \lambda \eta \theta \varepsilon \iota \alpha$ [sic] moves us beyond scientific and disciplinary rationality to the domain of Heideggerian obiter dicta and philosophical hocus-pocus, historical truth is firmly attached to the practice and rationality of historical discussion. Representational truth, the kind of truth embodied in a representation's presented, does not carry us to the domain of myth and of irresponsible and arbitrary speculation. (113)

But it remains unclear how one can avoid "irresponsible and arbitrary speculation" and save rationality (113) if one accepts "a loss of articulateness in the sense of excluding propositional truth" (109). Can there be rationality without propositional truth? Maybe some people indeed have revelations from reading history books - but even if this is so, it is hard to see how one can expect disciplinary rigor in such matters. 
In order to understand Ankersmit's position better, I propose that we bracket the discussion of reference and talk about extension. Let us try to analyze what he denies. Here is a transparent account of historical representation that one may want to contrast with Ankersmit's opaque one, in order to understand the latter better. ${ }^{34}$ Human beings (including historians and their readers) have thoughts, and these thoughts have contents in the form of concepts or propositions. Both concepts and propositions possess certain conditions of satisfaction - the conditions that need to be satisfied for an entity to be subsumed under a given concept, or the conditions that need to be satisfied for a given proposition to be true. An item (a thing, an event, a situation, or something else) can satisfy the conditions of satisfaction of many different concepts and be defined (its identifying description stated) in many different ways - this amounts to the rejection of essentialism. Let us say that an item that satisfies the conditions of satisfaction defined by a concept or a proposition is this concept's or proposition's extension. Concepts and propositions on this account are language-independent, and linguistic items such as words, phrases, or sentences are mere tools to express them.

Let us now consider how this account would apply to history-writing and especially to colligatory concepts. A historical narrative, from this point of view, is a set of sentences that expresses a set of propositions. As we have seen, the sum of the propositions expressed by a narrative is not the same as the sum of propositions expressed by each individual sentence belonging to the narrative. What happens then with colligatory concepts, such as the one expressed by the term "the Renaissance"? Its extension will be a set of trends (types of events, actions, motivation, worldview, and so on) that are characteristic of Italian life of the fifteenth and sixteenth centuries and that differentiate it from previous and subsequent centuries. These trends can be conceptualized as the subsidiary concepts of the wider colligatory concept "Renaissance." Here belong intensified cultural and intellectual production whose artifacts differ significantly from those of the previous centuries, intensified interest in classical antiquity that coincided with the influx of Byzantine scholars, the importation of Greek manuscripts and the ability to disseminate knowledge using the printing press, increased independence of intellectuals from the Church, and so on. The colligatory concept is not random, because Italian cultural and intellectual life of the period indeed differs from the preceding and later periods in these aspects. Well before the term "Renaissance" came into use, it was known that Italian life differed that way from other periods-well before Michelet used the metaphor of rebirth, Hegel described that which we call the Renaissance today, and used the term "Restauration.." ${ }^{35}$ Also,

34. I follow here roughly the account of satisfaction from John Searle's Intentionality (Cambridge, UK: Cambridge University Press, 1983), 11-13.

35. G. W. F. Hegel, Vorlesungen über die Philosophie der Geschichte (Frankfurt am Main: Suhrkamp, 1986), 488-491. 
it would be futile to attempt to state a single cause of the events and tendencies that make up the Renaissance, simply because no event ever has a single cause. ${ }^{36}$ A colligatory concept such as the one expressed by the term "the Renaissance" is more comparable to the descriptions of medical syndromes, whereby one can observe a series of symptoms, signs, and phenomena in the patient that can be correlated without having a common cause.

Taking all this into consideration, it is interesting to ask whether Ankersmit could say that the concept expressed using the term "Renaissance" has extension or not. His claim that the term "has no counterpart in the past itself" (83) suggests that he would argue that the extension of the concept is an empty set. But it is hard to see on what grounds this is so. Unlike "reference" defined his way, the extension of a concept expressed by a term can be an immaterial item (such as a set of events). Further, the fact that there exists a certain variation in the extensions of the concepts that various scholars express using the term "Renaissance" does not mean that these concepts have no extension. Predominantly they do have the same extension, with some variation. This variation has to be marginal, otherwise the very field of Renaissance studies could not be constituted. Finally, it makes no sense to say that there is no evidence that the Renaissance happened (the third argument) - not only because the evidence is overwhelming, but because this concept was originally created in order to colligate the trends and events that were known to differentiate the Italian culture of that period from the preceding and subsequent eras. In Walsh's phrase, the concept was "tailored to fit the facts." ${ }^{37}$ The term "Renaissance" may thus have no reference according to Ankersmit's definition of reference, but the concept it expresses does have its extension, according to the definition proposed here.

What does it mean to talk about the truth of a historical representation in the transparent model? The concept "Renaissance" is a colligatory concept that includes a number of subsidiary concepts, such as "revived interest in classical antiquity," "discovery and use of perspective in paintings," "increased availability of original Greek texts," and so on. The fact that the extensions of these concepts are not empty sets means that the extension of "the Renaissance" is not an empty set, and the proposition expressed by the sentence "the Renaissance happened" is true. Concepts cannot be true or false, but propositions can, and we should consider the truth or falsity of the propositions expressed by a historical text. This also includes the propositions expressed via rhetoric, the judgments the historian expressed, the propositions to be inferred from the examples the historian provided, what can be inferred about the historian's biases from the text, and so on. It is all these propositions that historians discuss when they discuss the accuracy or truth of a historical representation that a book offers, some of which may be very general (for instance, those that state the general perspective that the author advocates). In my experience, this is exactly the kind of debate that is really going on between historians.

36. If I drop a book and it falls to the floor, gravity is one of the causes, but also the fact that I did not prevent it from falling with my other hand, the fact that it was not tied with a rope to my hand, the fact that I did not drop it above the desk that could have stopped it from falling to the floor, and so on. 37. Walsh, "Colligatory Concepts," 139. 
An inverted parallel (if I may use that phrase) exists between Ankersmit and E. H. Gombrich. In Art and Illusion, Gombrich articulated a number of antirealist and cultural-constructivist positions and then spent the next forty years combating the antirealist and cultural-constructivist endorsements (appropriations, as he perceived it) of his book..$^{38}$ Ankersmit's philosophical views about narration have been endorsed and criticized as postmodernist chiefly because of his public endorsement of postmodernism (such as his article "Historiography and Postmodernism" that triggered the exchange with Perez Zagorin $\left.{ }^{39}\right)$. Nevertheless, even in his early Narrative Logic (which is regarded as his most postmodernist book) he assumes that there are statements that refer "to past reality" - not that they construct that reality. ${ }^{40}$ Similarly, in Historical Representation, he rejects the "extremist deconstructivist or narrativist" view "that thought or representation actually 'makes' or 'creates' reality." ${ }^{41}$ A recent book by Peter Icke clearly expresses the postmodernists' disappointment with Ankersmit's later development-and one can easily imagine that the disappointment is going to be even greater after this latest book. ${ }^{42}$

A reader who is not aware of all this, and who does not know when the book was published, will spontaneously date it to the 1970s because of the authors Ankersmit cites as "contemporary" and because of his tendency to insist on endorsing relativist positions that are unrelated to the topic-a tendency that can only unnecessarily harm the credibility of the book in the eyes of those readers who do not subscribe to the very specific brands of relativism that he happens to advocate. An example is the gratuitous and unconvincing assault on Kantian ethics very early in the book. ${ }^{43}$ Similarly, the statement "if there is just one thing

38. Gombrich actually wrote that "there is no reality without interpretation." Ernst Gombrich, Art and Illusion: A Study of Psychology of Pictorial Representation (London: Phaidon, 1960), 363. His subsequent attacks on the antirealist and cultural-cultural constructivist interpretation of his book caused some particularly vitriolic debates - see, for instance, Joseph Masheck, "Alberti's 'Window': Art-Historiographic Notes on an Antimodernist Misprision," Art Journal 50 (1991), 34-41, and Murray Krieger, "The Ambiguities of Representation and Illusion: An E. H. Gombrich Retrospective," Critical Inquiry 11 (1984), 181-195, as well as the response by Ernst Gombrich, "Representation and Misrepresentation," Critical Inquiry 11 (1984), 195-201.

39. Frank Ankersmit, "Historiography and Postmodernism," History and Theory 28, no. 2 (1989) 137-153; Perez Zagorin, "Historiography and Postmodernism: Reconsiderations," History and Theory 29, no. 3 (1990), 263-274; Frank Ankersmit, "Reply to Professor Zagorin," History and Theory 29, no. 3 (1990), 275-296.

40. Ankersmit, Narrative Logic, 103. Quite in line with this, he "condemns" the postmodernist view of statements in his "Reply to Zagorin," 278, esp. note 7.

41. Ankersmit, Historical Representation, 45.

42. Peter Icke, Ankersmit's Lost Historical Cause (New York: Routledge, 2012). See also Adam Timmins's review with the author's response in Reviews in History: http://www.history.ac.uk/ reviews/review/1245 (accessed September 1, 2013).

43. Ankersmit says that Kant's "conviction that values must be eternally valid in order to have the authority to guide us in our moral dilemmas" is "at odds with what history has on offer" because "[a]ny historian, whether historicist or not, will recognize that no (moral) values have been accepted 
that all contemporary philosophers, of whatever denomination, agree about, it is that language determines experience, and not the other way around" (214) clearly belongs to the 1970s. Indeed, Ankersmit supports it by citing Sellars, Rorty, Davidson, Quine, Derrida, and even (inaccurately) Gombrich, who all stated their views between four and six decades ago. ${ }^{44}$ They are certainly not our contemporaries. ${ }^{45}$ The view that language determines thinking and experience has been largely abandoned since the 1980s due to the influence of John Searle's work as well as extensive research on the thinking of animals and prelinguistic infants. ${ }^{46}$ In fact, by this time the proponents of the view that all thinking is verbal are describing themselves as fighting against the majority view. ${ }^{47}$ The affirmative tone in which Ankersmit talks about the linguistic turn $(26,114,196)$ is also reminiscent of the $1970 \mathrm{~s} \mathrm{era}{ }^{48}$ The same applies to his tendency not to differentiate between thoughts and their linguistic expressions and to the endorsement of Saussure's view that words and concepts are like two sides of the same paper and that one cannot cut on the one side without cutting on the other. ${ }^{49}$ Notoriously,

as valid for all times and places" (5). Certainly, Kant would have known that different values (or what were regarded as values) were accepted in different contexts. He would also have known that it is easy to respond that social, cultural, or historical context can obscure noncontextually valid values - and from this, it is easy to claim that one needs the light of reason to reveal these values. The Enlightenment, Kant famously said, is liberation from tutelage, and he defined the latter precisely as the incapacity to use one's own reasoning capacities (Verstand) independently of other people (that is, the social context). Ankersmit's argument is further marred by the claim that "as moral beings we are historically conditioned" while somehow "the historicity of norms and values is by no means incompatible with rational criticism of them. On the contrary, reason may unite and guide us in our debates about what more order we prefer and how to achieve it" (6). But he does not explain how a historically conditioned moral being can transcend its historical conditioning and formulate a historically nonrelative rational criticism of its moral norms and values. If one wants to argue moral relativism, there are certainly more sophisticated ways to do it; Ankersmit's book simply does not need to engage in this debate.

44. The reference to Gombrich in this context is inaccurate. In Art and Illusion (90) Gombrich did discuss favorably the view (that he attributed to Benjamin Lee Whorff) that language does not give names to pre-existing things or concepts so much as it articulates the world of our experience. But this needs to be read in the context of his subsequent opposition to the social-constructivist readings of this book. The 1972 version of his essay "Icones symbolicae" (Symbolic Images: Studies in the Art of the Renaissance [London: Phaidon, 1972], 165) rejects the view that it is we who, through language, create the categories and even the stable objects of our experience, "simply because language is a social institution that has evolved along lines of utility" (165).

45. Remarkably, in his written response to Paul Roth's criticism at the recent History and Theory Conference (Ghent, June 10-13, 2013) that "contemporary Anglo-Saxon philosophy" leaves no room for Ankersmit's kind of argument, Ankersmit agreed that "twentieth-century Anglo-Saxon philosophy" is of little help.

46. See Searle, Intentionality. For research about the thinking of animals and prelinguistic infants, see José Luis Bermúdez, Thinking without Words (Oxford: Oxford University Press, 2003).

47. See Christopher Gauker, "On the Alleged Priority of Thought over Language," in John Searle's Philosophy of Language: Force, Meaning and Mind, ed. Savas Tsohatzidis (Cambridge, UK: Cambridge University Press, 2007), 125-142.

48. Arguably, by this time it is not even clear what the term means. See Judith Surkis, "When Was the Linguistic Turn? A Genealogy," American Historical Review 117 (2012), 700-722.

49. He does admit that representations need not be in language (paintings are not; animals have representations without language) (154) and complains about "the lingualist prejudices with which we have been indoctrinated in one and a half centuries of the philosophy of language" (154). He also directly states that "[historical] representation both logically and temporally precedes language" (85). Nevertheless, the book often fails to separate clearly between thinking and language; Ankersmit often uses the word "language" where someone who makes such separation would normally use "think- 
if Saussure were right, then translation from one language into another would be impossible: a word in one language often expresses a set of concepts that does not correspond to any single word in another language (in which a number of words may be used for the same set of concepts) - and if words and the concepts they express were indeed inseparable as Saussure claimed, then a user of one language would never learn to differentiate the concepts that are necessary in order to use properly the words of another language. ${ }^{50}$ Even the understanding of human visuality in Ankersmit's book has an unnecessary 1970s tone because of the endorsement of Nelson Goodman's critique of the resemblance theory of representation (77). Goodman claimed that all visual representation is always conventional and cannot be based on objective resemblance: that, for instance, the similarity between a realist painting and the landscape that it depicts is not objective, but is generated by one's cultural background.$^{51}$ In his time, he could rely on "New Look" psychological research that emphasized the role of conceptual knowledge and expectations in the formation of human visual experience. Fifty years later, such an understanding of human visuality has been abandoned both because of the extensive body of philosophical studies on the nonconceptual

ing." One thus reads about the "parallelism of language and reality" $(12,13)$; how "language [and not thinking] is related to the world" (103); about the "gap between language and reality." (107) He also assumes that propositions, as truth-bearers, the entities that are normally assumed to be true or false, are language-dependent (107) and that in the case of propositional truth, "Language is then the home of truth" (109). For Saussure. see p. 142: sign and meaning, says Ankersmit, "come infinitely close together."

50. For instance, the German "scharf" expresses the concepts that correspond to English "sharp" or "spicy," and if Saussure were right, a native German speaker could never learn to differentiate between these two concepts, nor learn to translate "scharf" into English properly, since this would be like cutting the paper on the side of concepts without cutting it on the side of words. Saussure indeed states a couple of similar examples - that French mouton stands for English mutton and sheep or that French louer stands for German mieten and vermieten-but he uses these examples merely in order to argue that words do not stand for pre-existing concepts, in which case they would all have exact equivalents in meaning from one language to the next. (Ferdinand de Saussure: Course in General Linguistics [New York: Columbia University Press, 2011], 116.) He fails to see that such examples, combined with his view that words and concepts are like two sides of the same piece of paper (113) make it impossible for him to explain the human capacity to translate from one language into another. Indeed, he comes very close to recognizing this problem when he states that it is very hard for a French speaker to learn a Slavic language because Slavic languages differentiate between the aspects of verbs. However, if his description of the relationship between concepts and signs were accurate, this would not be merely difficult, but impossible. Generally speaking, once one assumes a strong relationship between words and thoughts, it becomes impossible to explain translation between languages (see Branko Mitrović, "Intentionalism, Intentionality, and Reporting Beliefs," History and Theory 48, no. 3 [2009], 180-198).

51. Nelson Goodman, Languages of Art: An Approach to a Theory of Symbols (Indianapolis, IN, and Cambridge, UK: Hackett Publishing Company, 1976). Ultimately, the argument fails because Goodman was not able to show that that a perspectival representation does not deliver to the eye a bundle of light rays equivalent to the one that would reach the eye from the depicted object itself-his geometrical proofs against perspective were fallacious. See David Carrier, "Perspective as a Convention: On the Views of Nelson Goodman and Ernst Gombrich," Leonardo 13 (1980), 283-287 (see also the subsequent exchange in Leonardo 14 [1981], 86-87). Similarly, see David Topper, "On the Fidelity of Pictures: A Critique of Goodman's Disjunction of Perspective and Realism," Philosophia 14, no. 1-2 (1984) 187-197, and also, without mentioning Goodman directly, but criticizing his arguments, David Topper, "Perspectives on Perspective: Gombrich and His Critics," in Richard Woodfield, The Essential Gombrich (London: Phaidon, 1996), 85. I attempted to provide a full survey of Goodman's geometrical errors in Branko Mitrović, "Nelson Goodman's Arguments against Perspective," Nexus Network Journal 15 (2013), 51-62. 
contents of human perception and because psychological research has shown that human vision is impenetrable for our knowledge, beliefs, and expectations. ${ }^{52}$

All this confirms that, contrary to Icke's concerns, Ankersmit's commitments to the antirealist and cultural-constructivist paradigm should be seen as firm and sound. It is important to understand that his emphasis on the opacity of historical representations is vital for the formulation of the constructivist paradigm in the philosophy of history. Ankersmit's has never been radical constructivism - such as Nelson Goodman's or the position from which Norman Bryson attacked Gombrich, claiming that all reality is historically constructed ${ }^{53}$ Rather, for Ankersmit, as well as for Hayden White or Keith Jenkins, there is reality, and historians can make individual true statements about it.$^{54}$ The connection with reality is lost only when such statements are organized into clusters of text, historical narratives, or representations, because other forces (rhetoric, literary style, political agendas, and so on) take over. To sustain this position, one has to argue that the relationship between a historical representation and the statements that constitute it is opaque. If it were transparent, then the truth, reference, or extension of a historical representation or narrative would be, in some transparent way, a function of the truth, reference, or extension of the totality of propositions of the statements that make up the narrative. The important contribution of Ankersmit's book is in his efforts to present a general theory of this opacity, without making commitments to some specific forces that may generate it. This should not be taken as faint praise: in spite of all my complaints about the details of the book, from the point of view of the postmodernist paradigm that Ankersmit promotes, his is arguably the most comprehensive philosophical perspective on the problem formulated so far, and his book has much to teach us about the postmodernist approach to historiography. But I should probably add that it does not make me share Ankersmit's faith in the approach.

\section{Norwegian University of Science and Technology, Trondheim}

52. For research on nonconceptual content, see José Bermúdez and Arnon Cahen, "Nonconceptual Mental Content," Stanford Encyclopedia of Philosophy (Spring 2011 Edition), ed. Edward N. Zalta, http://plato.stanford.edu/entries/content-nonconceptual/ (accessed February 10, 2014). For a collection of influential research papers on nonconceptual content, see Essays on Nonconceptual Content, ed. York Gunther (Cambridge, MA.: MIT Press, 2003). See also Bill Brewer, "Perceptual Experience Has Conceptual Content" and Alex Byrne, "Perception and Conceptual Content," in Contemporary Debates in Epistemology, ed. Matthias Steup and Ernest Sosa (Malden, MA: Blackwell, 2005), 217230 and 231-250. For the impenetrability of vision, see Zenon Pylyshyn, "Is Vision Continuous with Cognition," Behavioral and Brain Sciences 22 (1999), 341-365; idem, Seeing and Visualizing: It's Not What You Think (Cambridge, MA: MIT Press, 2006); idem, Things and Places: How the Mind Connects to the World (Cambridge, MA: MIT Press, 2007). Athanassios Raftopoulos, Cognition and Perception (Cambridge, MA: MIT Press, 2009), is particularly useful since it directly relates the discussions of nonconceptual content to the psychological research on impenetrability.

53. Nelson Goodman, Ways of Worldmaking (Hassocks, UK: The Harvester Press, 1978); Norman Bryson, Vision and Painting: The Logic of the Gaze (London: Macmillan, 1985).

54. Hayden White, Metahistory: The Historical Imagination in Nineteenth-Century Europe (Baltimore: John Hopkins University Press, 1973), 6, note 5; Keith Jenkins, Re-thinking History (London: Routledge, 1991), 40. However, in his Refiguring History: New Thoughts on an Old Discipline (London: Routledge, 2004), he claims that "historians can just never get things right" (5). 